\title{
Economics Education and Greed
}

\section{Citation}

Wang, Long, Deepak Malhotra, and J. Keith Murnighan. 2012. Economics Education and Greed. Academy of Management Learning \& Education 10, no. 4. doi:10.5465/amle.2009.0185.

\section{Permanent link}

http://nrs.harvard.edu/urn-3:HUL.InstRepos:41555832

\section{Terms of Use}

This article was downloaded from Harvard University's DASH repository, WARNING: This file should NOT have been available for downloading from Harvard University's DASH repository.

\section{Share Your Story}

The Harvard community has made this article openly available.

Please share how this access benefits you. Submit a story.

Accessibility 


\title{
ECONOMICS EDUCATION AND GREED
}

\author{
Long Wang \\ Kellogg School of Management \\ Northwestern University
}

Deepak Malhotra

Harvard Business School

Harvard University

J. Keith Murnighan

Kellogg School of Management

Northwestern University 


\begin{abstract}
We present three studies using multiple methods to assess the effects of economics education on greed. Study 1 shows that economics majors and students who had taken multiple economics courses kept more money in Dictator Games. Study 2 shows that economics education was associated with more positive attitudes towards greed and towards one's own greedy behavior. Study 3 shows that a short statement on the benefits of self-interest could bolster greed's moral acceptability.
\end{abstract}




\section{ECONOMICS EDUCATION AND GREED}

The first decade of this century has witnessed a string of seemingly outrageous acts of greed. Bernie Madoff’s long-running Ponzi scheme bilked investors of over $\$ 60$ billion; Dennis Kozlowski, then CEO, was convicted of stealing over \$600 million from Tyco; and, even when no laws were broken, the Financial Times' (2002) reported that as the 25 largest bankruptcies between 1999 and 2001 wiped out \$210 billion in shareholder value and almost 100,000 jobs, top management walked away with a combined $\$ 3.3$ billion in compensation. In the same year, Fortune reported that executives and directors of 1,035 corporations pocketed $\$ 66$ billion even as their companies' stock prices fell more than 75\%; in their “Top 25," 466 executives received $\$ 23$ billion from insider stock sales - an average of almost \$50 million each (Gimein, 2002).

Paul Volcker, the former chairman of the Federal Reserve Board, commented that “corporate greed exploded beyond anything that could have been imagined in 1990" (Cassidy, 2002). Alan Greenspan (Economists, 2002), his successor, warned that "an infectious greed seemed to grip much of our business community," because "the avenues to express greed have grown so enormously." More recently, President Obama (2009) reflected on "the attitude that's prevailed from Washington to Wall Street to Detroit for too long; an attitude that valued wealth over work, selfishness over sacrifice, and greed over responsibility."

Although people tend to almost universally condemn greed, particularly when it drives other people's behaviors rather than their own, establishing a clear definition of greed is tremendously problematic, as is the conceptual differentiation of greed and self-interest. In his historical analysis, Balot (2001:1) defined greed as "an excessive desire to get more... a primarily materialistic type of desire." What constitutes "excessive," however, may be a matter of opinion that can depend on a person's own acquisitive tendencies: people with strong materialistic drives, for instance, may be far more forgiving than ascetics. Thus, although people 
have no problem engaging in discussions about greed, drawing a line between self-interested action and greedy action is particularly difficult.

Behavior "on Wall Street" may represent the most obvious, modern embodiment of the role that greed can play in the structure of society, and of the difficulty in differentiating between self-interest and greed. In the corporate world, fiduciary responsibilities legitimize a push for greater profits; the desire to out-perform competitors and ward off new entrants, however, can easily tempt managers to engage in illegitimate behavior (e.g., Murnighan, 1991). Prior to the recent subprime mortgage crisis, for example, many broker-dealers invested in high-risk collateralized debt obligations (CDOs) to offer higher returns than their competitors (e.g., to money-market customers); this helped fuel the demand for subprime mortgages and provided an incentive for mortgage brokers to make loans to customers who did not have the ability to pay them back (Wilson, 2007). This example is consistent with Plato's moral argument against greed (Frost, 1962): individual greed benefits one person at the expense of others; systemic greed can damage an entire system. Alan Greenspan (2002), for example, in describing the financial system at the turn of the century, argued that "at root was the rapid enlargement of stock market capitalizations in the latter part of the 1990s that arguably engendered an outsized increase in opportunities for avarice." Although the individual behaviors that created such havoc can be viewed as rational attempts to maximize profits, even ardent defenders of neoclassical economics have suggested that it is more aptly described as a manifestation of greed (Greenspan, 2002).

The language of economics makes it especially difficult to differentiate self-interest from greed. Economics has long portrayed people as rational profit-maximizers, i.e., homo economicus, and the assumption of self-interest, embodied in the desire to maximize gains and minimize losses, is central to most economic models (Frank, Gilovich \& Regan 1993). A critical and inherent problem in an economic approach to greed is that the push to maximize gains does 
not include a stopping rule: the accumulation of gain need see no end other than externally imposed constraints. Instead, rational economic action seems to imply unlimited and unrelenting consumption (Schwartz, 1986).

A central motivation of this paper is to evaluate the potential link between economics education and the kinds of nefarious business decisions described previously. Notably, many faculty members at business schools around the world have been trained in and teach economics, directly (e.g., finance courses) or indirectly (e.g., strategy courses). Their influence on management and organizations is enormous and pervasive (Ghoshal \& Moran, 1996). Others have previously noted the possibility that the assumptions and language of economics may have had an unintended negative influence on management practices (e.g., Ferraro, Pfeffer \& Sutton, 2005; Ghoshal, 2005; Pfeffer, 2005; Rocha \& Ghoshal, 2006). Managers and leaders with heavy economics-oriented training may feel justified in relentlessly pursuing organizational and individual self-interest (Ghoshal, 2005) and, absent restraint, acts of excessive selfishness and greed (Folger \& Salvador, 2008).

While others have made cogent theoretical arguments that an over-reliance on economics models and assumptions is dangerous (e.g. Ghoshal, 2005; Pfeffer, 2005; Rocha \& Ghoshal, 2006), the literature is short on data (Pfeffer, 1993; 2005). Thus, this research tests the basic, fundamental prediction that economics education will lead people to hold more positive views of greed. In addition, because economic models tend to ignore the impact of self-interested behavior on the welfare of others, we also test two important corollaries of this theoretical prediction, that studying economics will lead people to ignore the effects of their own behavior on others and to more comfortably engage in greedy behavior. Specifically, in our first two studies, we investigated the association between economics coursework and individuals' greedrelated perceptions and behaviors. Because self-selection problems are inevitable when studying 
the impact of real-world education, Study 3 was designed to replicate the findings of Studies 1 and 2 in a laboratory environment that could eliminate self-selection.

\section{SELF-INTEREST, GREED, AND ECONOMICS}

Self-interest is the fundamental assumption of rational choice models in economics. Adam Smith, the father of classical economics, introduced the concept of self-interest as the dominant theme in his classic, The Wealth of Nations (Stigler, 1971). One of Smith's most memorable and impactful lines suggests that individuals should act self-interestedly, without benevolence or concern for negative externalities, because "it is not from the benevolence of the butcher, the brewer, or the baker, that we expect our dinner, but from their regard to their own interest" (Smith, 1776/2007: 9-10). He also noted that "nobody but a beggar chooses to depend chiefly upon the benevolence of his fellow-citizens." More recent approaches echo similar ideas, e.g., "persons (should) be conceived as not taking an interest in the interests of those with whom they exchange" (Gauthier, 1986, p. 87).

Although the economics literature often lauds self-interest, it discusses greed far less often (Cameron, 2003). Notably, some scholars (e.g. Werhane, 1991) suggest that Adam Smith would view greed as antithetical to a well-run economic system. In the Theory of Moral Sentiments (1759/2002), Smith identified social passions as important motivating forces because economic systems could not function properly in the absence of social cooperation and coordination. Smith did not, however, distinguish greed from self-interest; instead, classic interpretations suggest that his work not only established self-interest as the key motivation underlying economic behavior, but also — perhaps without intending to — laid the groundwork for the legitimization of greed. For example, in his introduction to a reprint of The Wealth of Nations, Lerner claimed that Adam Smith "gave new dignity to greed and a new sanctification to the predatory impulses" (Lerner, 1937: ix). Similarly, Hirschman $(1977 ; 100)$ argued that "the main 
impact of The Wealth of Nations was to establish a powerful economic justification for the untrammeled pursuit of individual self-interest."

As noted, however, distinguishing self-interest maximization from greed is tremendously difficult. Although delineating precisely when self-interest becomes greed is beyond the scope of this paper, for our purposes, following Balot (2001), we distinguish between the two as follows: self-interest is a motivation, widely presumed to drive most economic behavior, which aims to increase personal well-being. In contrast, greed is self-interest taken to such an extreme that, based on prevailing social norms regarding the effects of one's behavior on others, it may be perceived as unacceptable or immoral.

Clearly, the central issue concerns a determination of the limits of acceptable self-interest. Conceptually, greed, or "excessive" self-interest, can be evaluated in reference to descriptive and injunctive situational norms (Cialdini, Kallgren, \& Reno, 1991) regarding self-interested behavior that imposes negative externalities on others. Thus, having "no stopping rule" when excessive behavior has no substantive impact on others, e.g., binge eating, does not implicate greed. Instead, a construct like "gluttony" may be more appropriate in this instance.

Operationally, then, we define greedy behavior as excessive acts of self-interest that impose costs on — or otherwise deprive the well-being of - others. There is clearly no universal “stopping rule" beyond which maximizing self-interest turns to greed, except as normatively defined. One of the problems this creates in behavioral analysis is that the same behavior may be perceived by one group as acceptable self-interest and by others as unacceptable greed. For this reason, attempts at studying "greedy behavior" without also evaluating perceptions of what is considered "greedy" are likely to produce ambiguous results. In the current research, we acknowledge that people can exhibit wide variation in their conceptual and behavioral definitions of greed; one of our primary objectives is to understand how this variation develops. 
Thus, we focus on whether economics education can push people, especially those who will become future managers and executives, to define and view greed positively, and behave accordingly.

\section{ECONOMIC THEORY, TRAINING, AND GREED}

Although we acknowledge that it may be completely unintentional, an increased exposure to economic theory may give people convenient frameworks that license greed. At least three distinct but complementary mechanisms might help to explain why and how economics training can affect greed-related attitudes and behaviors.

First, economic theory's assumption of self-interest maximization is so dominant and pervasive that the field of economics often overlooks other human motivations (Stigler, 1980; Sen, 1987; Fehr \& Gintis, 2007): homo economicus cares primarily about self-gain and little (if at all) for others' welfare. Thus, others' outcomes and the social utility that may be created (e.g., Loewenstein, Bazerman, \&Thompson, 1989) become, at best, secondary concerns. This deemphasis of the social consequences of one's actions may result in excessive (i.e., greedy) behavior (e.g., Ginzel, 1994). Wang and Murnighan (2010), for instance, found that one of the strongest predictors of an individual's ability to resist greed was a salient concern for others' outcomes; this factor was often absent when people succumbed to their greedy impulses. Notably, it also tends to be absent from the normative calculus espoused by most economic theories.

Second, game theory's emphasis on a cool analytic approach to interpersonal behavior (cf., Murnighan, 1991; Frank, 1988; Frank, et al, 1993), akin to the calculative approach of transaction cost economics (Williamson, 1984; 1994), may also contribute, unintentionally, to potentially greedy behavior. Interpersonal emotions like empathy and guilt (Eisenberg, 2000) do not fit within these frameworks. Instead, economic models imply that intelligent, rational people will analyze 
their interactions and their choices, coolly and clinically, and only focus on their own outcomes and the strategies that they can use to achieve these outcomes with the highest likelihood.

Related research suggests that moral emotions - e.g. shame, guilt, disgust, etc.—are among the most important elements of people's moral apparatus (Tangney, Stuewig \& Mashek, 2007). Moral emotions connect a person's behaviors to the interests or welfare of others, or to society as a whole (Hadit, 2003), providing motivations for appropriate behaviors and disincentives for inappropriate behaviors (Kroll \& Egan, 2004). A moral emotion like guilt, for example, can create strong internal feelings that effectively limit greed or extreme self-interest (Wang \& Murnighan, 2010). However, the rational and calculative approach of economic theories may crowd out the salient effects of moral emotions (e.g., Zhong, 2008). Thus, we expect that a repeated emphasis on calculation and rational economic analysis, and a subordination of the role of affect, will promote self-interest, potentially to the point of greed.

Third, research has found a relationship between economics training and beliefs that others are also motivated by self-interest (Frank, Gilovich \& Regan, 1996). These beliefs can create a false consensus, influencing people to think that most other people feel the same way that they do, and this can lead them to justify their own self-interested behavior (Miller, 1999) and reject alternative behaviors and beliefs (Ross, Greene \& House, 1977). For instance, individuals who have lied to another person often create a self-serving and unsubstantiated false consensus that leads them to see the recipient of their deception as dishonest, a phenomenon referred to as “deceiver's distrust” (Sagarin, Rhoads \& Cialdini, 1998). Economics education may create a similar false consensus about others' self-interest and greed, leading to a selffulfilling prophecy (Ferraro, Pfeffer \& Sutton, 2005) in which everyone finds it easier to selfjustify their own greedy behavior. 
Thus, by using decision-making models that subordinate considerations of others' welfare, emphasizing analyses that are devoid of affect, and by suggesting that others are likely to behave self-interestedly, economics training may fuel the tendency towards — and provide justifications for-greedy behavior. For example, transaction cost theories are consistent with this logic, suggesting that the goal of maximizing self-interest motivates individuals to act with guile, i.e., to engage in "the full set of ex ante and ex post efforts to lie, cheat, steal, mislead, disguise, obfuscate, feign, distort and confuse" (Williamson, 1984: 198). This argument also suggests that, despite its potential immorality and its potential to undermine an otherwise wellfunctioning economic system, perceptions that extreme self-interested action is legitimate may lead to deception, cheating, and/or fraud (cf., Murnighan, Cantelon, \& Elyashiv, 2001).

Prior work suggests that academic training does motivate economists and economics students to behave in ways that are more consistent with the predictions of economic models. In a public goods experiment, for example, Marwell and Ames (1981) found that economics graduate students contributed only $20 \%$ of their resources, while other students averaged over twice as much, at $42 \%$; the economics students were also more likely to free ride. Carter and Irons (1991) provide another example, demonstrating that economics students accepted less and kept more than other students did when they were playing an Ultimatum Game (cf., Güth, Schmittberger \& Schwarze, 1982).

Research also suggests that training in economics can promote behavior that is excessively, and perhaps illegitimately, self-interested. Frank et al. (1993) found that a semester of exposure to game theory led students to be less honest than students who took an economics course with less emphasis on the assumption of self-interest. Subsequent studies (e.g. Yezer, Goldfarb \& Poppen, 1996; Stanley \& Tran, 1998; Laband \& Beil, 1999; Frank \& Schulze, 2000) have challenged this conclusion, typically because students who are inherently self-interested may have self-selected 
into economics courses. Nonetheless, an accumulation of data continues to find a positive relationship between economics training and self-interested action. In addition, research has shown that MBA students - whose curricula tend to be steeped in economics - cheat more on exams than law school (McCabe, Dukerich \& Dutton, 1993) and other non-business students (McCabe, Dukerich \& Dutton, 1991). All of these findings suggest that economics training can encourage people to behave in ways that are consistent with the assumptions of economic models. In the current research, we push this further by suggesting that economics training may have two additional effects: reducing fairness concerns and leading to more positive perceptions of unrestrained self-interest, i.e., greed.

As noted, sustained exposure to the assumptions and tools of economics may do more than provide an appreciation of the virtues of self-reliance (Rand, 1957) and the value-creating potential of self-interest (Smith, 1776/2007). By subordinating considerations of the externalities of self-interested behavior, by crowding out the potential influence of affect, and by promoting beliefs that others are self-interested, it may also provide people with assumptions, language, and rationales (Ferraro, et al., 2005; Ghoshal, 2005; Pfeffer, 2005) that they can use to justify greedy behavior (Cameron, 2003). Thus, the current research investigates the influence of economics education on perceptions of greed and greedy action, and tests two complementary hypotheses:

H1: Increases in economics education will be associated with increasingly greedy action and decreasing concerns for fairness.

H2: Increases in economics education will be associated with increasingly positive perceptions of greed.

We conducted three complementary studies to test these hypotheses . Study 1 tested Hypothesis 1 by evaluating behavior in the Dictator Game (e.g., Forsythe, Horowitz, Savin, \& Sefton, 1994). Study 2 tested Hypothesis 2 by investigating people's attitudes towards their own 
greedy actions and their definitions of greed. Finally, to address a potential selection bias, Study 3 exposed non-economics majors who had not taken any formal economics courses to brief economic perspectives on self-interest to test whether exposure to the ideas of economics might influence their perceptions of greed.

\section{STUDY 1}

Study 1 is an initial behavioral test of Hypothesis 1, investigating whether taking economics courses leads people to be less concerned with fairness and to keep more money in a Dictator Game. The Dictator Game gives people complete discretion over how to divide a fixed amount of money between themselves and another, unknown person. Participants were given $\$ 10$, which they could share, if desired, with another person who had ostensibly received no endowment. Following prior research (Rapoport \& Chammah, 1965; Coombs, 1973), we viewed keeping more money as indicative of greater self-interest, and potentially greed. Economic models predict that rational dictators will keep the entire endowment and send nothing to the other person; people in Dictator Game experiments, however, often share, even when their endowments are large (Carpenter, Verhoogen, \& Burks, 2005).

It is difficult in a standard Dictator Game to clearly delineate where self-interest ends and greed begins: how much of an endowment must a person keep to tip the scale towards greed, beyond simple self-interest? To address this issue, and to create a context in which individuals' choices are both simple and clear, we also included a second, restricted version of the Dictator Game in which participants had two choices: keeping half of their endowment (\$5 of $\$ 10)$ or over $90 \%$ of it $(\$ 9.25$ of \$10), a fairly extreme, arguably greedy outcome. Hypothesis 1 predicts that greater exposure to economics training will lead people to keep more of their endowment and to be more likely to keep the lion's share of their endowment $(\$ 9.25)$ when their choices are restricted to "greedy" versus 
"equal" outcomes. It also predicts that, in explaining their decisions, dictators who have had more exposure to economics will be less likely to raise issues related to fairness.

\section{METHODS}

\section{Participants and Design}

A total of 112 students participated in the study: 67 from a micro- or macroeconomics economics class and 45 from an introductory or intermediate-level education class, all from the same Midwestern University. Participants volunteered immediately after the completion of an intermediate-level economics or education class session, in groups ranging in size from 6 to 40 . Participants had been in college for an average of 2.5 years, with no significant difference between conditions. Most economics students were male; $28 \%(\mathrm{~N}=19)$ were female; most education students were female; $18 \%(\mathrm{~N}=7)$ were male. Although no gender effects emerged, the small number of men in the education sample makes it difficult to evaluate gender effects with a high degree of power, a limitation we addressed by recruiting more non-economics majors in Studies 2 and 3.

\section{Procedures and Design}

Participants were told that they would make a series of decisions that involved the allocation of a sum of money between themselves and a randomly assigned counterpart. Half of the students were then taken into a different room. In each room, one of the authors read the instructions aloud as the participants read along. All participants were told that they had been assigned the role of Dictator for two decision-making tasks. ${ }^{1}$ In the unrestricted task, they were given $\$ 10$ to distribute between themselves and a randomly assigned counterpart in the other room: they could divide the money any way they wished. In the restricted task, they again had $\$ 10$ to allocate but this time they had to divide the $\$ 10$ equally or keep $\$ 9.25$ for themselves and give $\$ .75$

\footnotetext{
${ }^{1}$ The terms "dictator" and "Dictator Game" were never used. The task was described as a "decision-making" exercise and participants were told that they would play the part of "Player 1".
} 
to another randomly assigned counterpart. Thus, the experiment used a 2 (Course: economics/ education $) \times 2($ Task: restricted/unrestricted $)$ mixed design, with repeated measures on the task. Half of the participants made unrestricted choices first and half made restricted choices first. Everyone was told that they were randomly assigned to be a dictator and that they were paired with two different recipients in the other room (even though everyone was a dictator).

\section{Anonymity}

The procedures were designed to ensure that participants' decisions would be completely anonymous, and the experimenters took care to make sure that participants understood this. Each participant received an unmarked envelope that contained a task form for each decision; participants placed each completed form in its own envelope, and wrote a 4-digit code, of their choice, on the outside of each envelope. They then placed the two task envelopes into a larger, unmarked envelope so that the experimenter would not see their choices. When all of the participants in the room were finished, the experimenter took the larger envelopes out of the room and gave them to an administrator whom the participants never met and never expected to meet. The administrator randomly chose one of the two small envelopes, read the form in it, and put the appropriate amount back into the code-numbered envelope. The administrator gave this envelope to the experimenter, who delivered it to the room where the participants were sitting; they each picked up their own envelope, with the cash in it, on their way out.

\section{Fairness Concerns}

While the money was being placed into envelopes, participants completed a brief questionnaire in which they described the most important factors behind their decisions. A trained coder who was blind to the hypotheses and the conditions read each open-ended response and counted the number of times each participant used the word "fair" or any word with "fair" as its root (e.g., "fairness", "unfairly"). The word "fair" and its derivatives were chosen for coding 
because they represent terms that are commonly associated with a concern for how one's own behavior may affect others, a critical ingredient in our definition of greed. The authors did the same coding for a random sub-sample of 40 participants; the result, $100 \%$ agreement between the coders, suggests that the coders' counts were accurate.

\section{RESULTS}

As predicted, students in economics courses (a) kept more money than students in education courses in the unrestricted task, and (b) kept the larger amount (\$9.25) more often in the restricted task (see Table 1). In the unrestricted task, economics students kept an average of $\$ 7.80$; education students kept $\$ 6.26(\underline{\mathrm{t}}(107)=3.66, \mathrm{p}<.001$; Cohen's $d=.33)$. In the restricted task, $64.1 \%(\mathrm{~N}=41)$ of the economics students kept $\$ 9.25$ versus only $40.1 \%(\mathrm{~N}=26)$ of the education students $\left(\chi^{2}(2)=6.55, \mathrm{p}<.05\right)$; this meant that economics students kept, on average, \$7.72, and education students kept $\$ 6.74$ in the restricted task. These data support the first half of Hypothesis 1, which predicted that economics education would lead to more self-interested choices and, arguably, to more greed.

Self-reported, post-experiment responses on the factors that were important for their decisions bolstered this interpretation and supported the second half of Hypothesis 1, that economics and education students framed the situation and their actions differently. Education students made significantly more references to fairness and unfairness $(\mathrm{N}=40)$, implicating a concern for or evaluation of the outcome of others, than did economics students $\left(\mathrm{N}=31 ; \mathrm{t}_{(110)}=2.54, \mathrm{p}<.05\right)$. More than half of the education students $(\underline{56 \%})$ made at least one reference to fairness compared to less than one-third of the economics students $(\underline{31 \%})$.

\section{Supplemental Analysis: Behavior of Non-Majors}


Of the 64 economics-class students, 50 were economics majors and 13 listed another major; of the 44 education-class students, 30 were education majors and 13 listed another major. ${ }^{2}$ Although these are small samples, they allow us to consider the effects of an economics course on those who have not selected into the field but who have been exposed to economics models and assumptions (including immediately prior to the experiment). Comparing the two groups of nonmajors revealed that a much larger percentage $(61.5 \% ; \mathrm{N}=8)$ of non-majors who had just had an economics class kept the maximum possible than did non-majors who had just had an education course $(7.6 \% ; \mathrm{N}=1), \chi^{2}(2)=11.09, \mathrm{p}<.01$. Because the economics courses were advanced courses, all of the non-majors had taken at least one previous economics course. This suggests that nonmajors who had taken multiple economics courses responded much like economics majors.

\section{DISCUSSION}

Study 1 supports the prediction that studying economics leads to more self-interested and potentially greedy action: compared with students in an education class, students in an economics class kept significantly more money for themselves. Furthermore, when forced to choose between an even-split of their endowment and taking almost the entire amount, more than half of the economics students opted for the disproportionate advantage, while less than a third of the education students did. Their open-ended responses also suggest that exposure to economics promotes greater self-focus and less of an adherence to norms of fairness (Fehr \& Gintis, 2007). Notably, even if they were not economics majors, those walking out of an economics course kept more of the money than did non- majors walking out of an education course. These data provide a first suggestion that exposure to economics education may encourage the pursuit of greed.

Although the results are intriguing, they have several limitations. Keeping more of a $\$ 10$ endowment, for instance, could be clearly attributed to self-interest rather than greed. The

\footnotetext{
${ }^{2}$ None of these students majored in business or business-related fields because the school where Studies 1-3 were conducted did not offer any undergraduate business majors.
} 
phenomenology of the task, however, suggests that greed may have played a part because participants who had the dictator role did nothing to earn their endowment-i.e., they had no objective basis for deserving more. In addition, their counterparts depended entirely upon them for their outcome: they were equally undeserving, making an equal division of the money arguably fair (Messick, 1995).

A second potential issue is self-selection, as students can self-select into both their majors and their courses, and people who are more inclined to act with greed may also be more inclined to enroll in economics rather than in education courses. Compounding this issue is the gender distribution in our sample, with few female students in the economics class and few male students in the education class. Previous research suggests that men act more self-interestedly and are more likely to major in economics than women (Eckel \& Grossman, 1998). Unfortunately, there were too few men in the education course to allow for a reliable test of the effects of gender. Thus, we made it a point to test gender effects in Studies 2 and 3.

Study 2 moved away from the structure of the Dictator Game by asking participants to tell their own stories about greed; it tested Hypothesis 2's prediction that a greater exposure to economics education would lead to more positive perceptions about greed, in this case, in reference to one's own, self-described greedy actions. We also investigated the association between economics education and individuals' definitions of greed.

\section{STUDY 2}

Study 2 was designed to achieve two goals: to bolster the results of Study 1 without imposing a definition of greed, and to investigate the link between economics education (in terms of academic major as well as exposure to multiple courses) and the positivity of people's attitudes towards their own greedy actions. Thus, we asked participants to tell two stories about their own prior greedy behavior and to define greed, as they conceived of it. 


\section{METHODS}

\section{Participants}

A total of 166 undergraduates from a Midwestern university responded to an email invitation to participate in an online survey. They were offered $\$ 5$ to participate; $60 \%$ were female; 44\% were Caucasians; they averaged 20 years of age; and 34\% were economics majors.

\section{Procedure and Materials}

After a general introduction, the instructions indicated that we were studying greed. (Participants could withdraw at any time if they were not comfortable with the study; everyone chose to participate.) The instructions asked participants to tell two personal stories, one in which they had been tempted by greed and succumbed and one in which they had been tempted by greed but resisted (randomly-ordered). After each story, they evaluated their behaviors in the story on eight 7-point semantic differentials, three of which were reverse-coded: correct/wrong, justified/unjustified, regret/not, delighted/mortified, excited/depressed, good/bad, happy/sad, and satisfied/unsatisfied. They also responded to open-ended questions asking them to explain the reasons for their actions and the major factors behind their decisions in each story. Participants then rated greed, generally, as good/bad, moral/immoral, and correct/incorrect on 7-point scales (1=bad/immoral/incorrect; 7=good/moral/correct). Finally, prior to a request for demographic information, they were asked to define greed in their own words.

\section{Analyses}

\section{Majoring in economics vs. Exposure to economics.}

Our sample included many non-economics majors who had taken multiple economics courses: $62.5 \%$ had taken two or more; $18 \%$ had taken three or more. Because exposure to economics courses among non-majors might dampen the effects of a student's academic major, we analyzed the effects of completing more versus few economics courses in addition to the 
effects of being an economics major. Specifically, we report on a comparison of students who had taken three or more economics courses with those who had taken two or less. ${ }^{3}$

\section{Ratings and definitions.}

Our primary analyses focus on three conceptually different measures in this study: 1) people's feelings about their own greedy action; 2) their general moral views of greed; and 3) their definitions of greed. A factor analysis of participants' semantic differential ratings of their feelings indicated that one factor accounted for more than $68 \%$ of the variance in their 'succumbed to greed' stories, and $63 \%$ of the variance in their 'resisted greed' stories. Thus, we formed a single, post-hoc-feeling index by averaging their 8 ratings. (Cronbach's $\alpha$ was .94 and .92 for the succumbed and resisted stories, respectively). We also factor analyzed their general ratings of greed based on answers to whether greed was generally good, correct, or moral; these responses led to one factor that accounted for $77.68 \%$ of the variance in their ratings. Thus, we formed one index for their moral view of greed by averaging the three items (Cronbach's $\alpha$ was .85). Although people's self-reported ratings might affect each other, the two indexes did not show any reliable correlations (Cronbach's $\alpha$ was .49), suggesting that the two measures are statistically distinct.

Our definition of greed pertains to excessively self-interested behavior that goes against prevailing norms "regarding the effects of one's behavior on others." Thus, as before, we coded whether their definitions included a consideration of greed's influence on other people. As noted, game theoretic models take an individualistic, analytic approach to interpersonal interactions with little regard for the welfare of others. In addition, Vohs, Mead, and Goode (2008) predicted

\footnotetext{
${ }^{3}$ An analysis comparing the responses of students who had taken two or more economics courses versus those who had taken zero or one led to a similar, but weaker pattern of results across all of the analyses. In addition, there were no significant differences between students who had taken three or fewer economics courses and those who had taken four or more. This suggests that taking three economics courses may create a natural breaking point and, beyond that, taking additional courses has less impact.
} 
and found that thoughts about money made people less sensitive to others' needs. We wondered whether economic education would have a similar effect. The underlying logic here is that, when individuals acknowledge that interpersonal or social consequences are relevant, their decisions may be more likely to include appropriate "stopping rules" in their pursuit of self-interest. Thus, when participants indicated, even implicitly, that greed would make other people suffer, their definitions were coded as " $1 \mathrm{~s}$ "; otherwise, they were coded as " 0 s." Two research assistants, both blind to our hypotheses and to participant information other than ID codes, independently read and coded all of the definitions. Reliability was good (Cohen's Kappa=.73), so we used the coding from one of the research assistants for our analyses.

\section{Dependent variables.}

The analyses focused on three primary dependent variables: the post-hoc feeling index for the stories in which participants had succumbed to greed, their moral view of greed, and whether their definition included a consideration of greed's negative impact on others. (Analysis of the stories of resisting greed led to no significant differences across conditions.)

\section{RESULTS}

Majoring in economics seemed to shape participants' definitions of greed. In addition, exposure to multiple economics courses was positively related to participants' post hoc feelings toward their own greed(for both economics majors and non-economics majors who succumbed to greed), and to more positive views regarding the morality of greed (for non-economics majors). Finally, we observed a gender effect on post hoc feelings toward one's own greed. Table 1 reports the correlation among the variables. We report the effects on the three major dependent variables separately.

\section{Moral Views of Greed}


In general, participants viewed greed quite negatively: the mean was $1.61(\mathrm{SD}=1.15)$ on a 7-point scale from $1=\mathrm{immoral} / \mathrm{bad} /$ incorrect to $7=\mathrm{moral} / \mathrm{good} /$ correct. Both being an economics majors $(\mathrm{r}=.15, \mathrm{p}=.06)$ and the number of economics courses a person had taken $(\mathrm{r}=.22, \mathrm{p}<.01)$ were positively related to moral views of greed. A gender $\times$ major $\times$ exposure (having taken three or more versus two or less economics courses) ANOVA on individuals' moral views of greed led to two significant interactions: gender by major $\left(F(1,158)=4.22, p<.05 ; \eta^{2}=.03\right)$ and major by exposure $\left(\mathrm{F}(1,158)=4.34, \mathrm{p}<.05 ; \eta^{2}=.07\right)$. Figure 1a shows that taking three or more courses was associated with significantly more positive views of greed for non-economics majors (F (1, $108)=7.56 ; \mathrm{p}<.01 ;$ Cohen's $d=.54)$ but not for economics majors $(\mathrm{F}(1,54)=.50, \mathrm{p}=.48)$ : noneconomics majors who took multiple economics courses viewed greed as economics majors did. Figure $1 \mathrm{~b}$ shows that being an economics major was also associated with significantly more positive views of greed for women $(\mathrm{F}(1,108)=13.14$, $\mathrm{p}<.001$; Cohen's $d=.51)$ but not for men $(\mathrm{F}$ $(1,54)=.04, \mathrm{~ns})$ : female economics majors viewed greed as male economics majors did.

\section{Post-hoc Feelings Toward One's Own Greed}

Again, the number of economics courses a student had taken was positively related to their feelings about their own greedy actions $(\mathrm{r}=.17, \mathrm{p}<.05)$ but being an economics major was not $(\mathrm{r}=.07, \mathrm{p}=.36)$. A gender $\times$ major $\times$ exposure ANOVA on individuals' moral self-evaluations led to a significant effect for gender $\left(F(1,158)=6.26 ; p=.05 ; \eta^{2}=.02\right)$ and a marginally significant effect for exposure $\left(F(1,158)=4.67 ; p=.09 ; \eta^{2}=.02\right)$ but not for being an economics major $(F(1,164)=.85)$. Students who had taken three or more economics courses had significantly more positive feelings about their own greedy actions than students who had taken two or less, $(\mathrm{F}(1,164)=7.13, \mathrm{p}<.001$; Cohen's $d=.33)$. Women's moral feelings towards their own greedy actions were significantly more negative than men's: $(\mathrm{F}(1,164)=8.72, \mathrm{p}<.01$;

Cohen's $d=.37)$. 


\section{Definitions of Greed}

Logit regression analysis with definition of greed as the dependent variable and major, gender, and exposure as independent variables revealed one significant effect, for majors $(\beta=.86$, $\mathrm{p}<.05)$ : economics majors mentioned greed's social costs significantly less often $(30 \%)$ than non-economics majors did $\left(53 \% ; \chi^{2}=7.32, \mathrm{p}<.01\right)$. Table 3 reports the regression results. After controlling for students' majors, neither gender $(\beta=-.40, p=.56)$ nor taking multiple economics courses $(\beta=-.54, p=.16)$ had a significant effect on mentions of greed's social costs.

\section{Summary}

These results support Hypothesis 2, which predicted that economics education would be positively associated with perceptions of greed. Study 2 identified three factors that influenced individuals' feelings and attitudes about greed: the number of economics courses they had taken, being an economics major, and gender. Being an economics major also seemed to affect individuals' definitions of greed. Taking three or more economics courses had two effects: it was associated with more positive perceptions of one's own greedy action, regardless of the person's major, and it was associated with more positive moral views of greed for non-economics majors. Finally, Study 2's results also revealed that women felt worse about their own greedy behavior than men did (Seguino, Stevens \& Lutz, 1996; Eckel \& Grossman, 1998). Interestingly, while women were less likely to major in economics, ${ }^{4}$ women who were economics major had a more positive attitude toward greed, much like men's.

\section{DISCUSSION}

Study 2's results on people's perceptions and definitions were consistent with the behavioral results of Study 1 and with our hypotheses: economics education was associated with more positive perceptions of greed generally and of one's own greedy action; it was also

\footnotetext{
${ }^{4}$ Only $18 \%$ of the female students in our sample majored in economics.
} 
associated with definitions of greed that were less cognizant of the impact of greedy action on others. It seems reasonable to infer that these results might stem from repeated exposure to the language, assumptions, and models of self-interest maximization.

The methods in this study did not exert any control over the content and scope of our participants' greedy stories: to make their recall task easy, we gave them free rein to decide which story to tell. Thus, their stories might reflect a variety of biases (Schwarz, Groves, \& Schuman, 1998; Weingart, 1997). While it is conceivable that people who took multiple economics courses tended to recall different types of greedy behaviors than those who had less exposure, we have no grounds for expecting such a difference, nor do the stories themselves seem to suggest such a difference. Finally, while our analyses distinguished between being an economics major and taking multiple economics courses, it is difficult to completely tease apart some of these effects. To address these concerns, Study 3's sample consisted entirely of people who had little exposure to economics education and, to exert greater control, we experimentally manipulated an economics mindset by presenting our participants with statements about selfinterest prior to their evaluations of greed.

\section{STUDY 3}

Study 3 assessed the effects of positive or negative statements about self-interest on people's attitudes and opinions about greed. Because there is at best a fine line, if any, between maximizing self-interest and greed, we expected that statements that justified self-interest from a purely economic perspective might also legitimize greed. By using quotes from famous economists, we tried to mimic, albeit in reduced form, some of the arguments that might repeatedly surface in economics lectures and seminars. Specifically, participants read either positive or negative statements on self-interest and then reported their opinions of greed. In addition, we only included non-economics majors who had not taken any economics courses. 
Thus, we restricted the characteristics of our sample in an attempt to eliminate the effects of selfselection. If we observe results that are similar to those of Studies 1 and 2, they will help to mitigate concerns that self-selection can account for the results of our research.

\section{METHODS}

\section{Participants and Procedure}

The participants were 92 undergraduates, averaging 19.8 years of age; $69 \%$ were female. None were economics or related majors and none had formally taken any economics courses before. Thus, the participants had no exposure to formal economics education.

After reading some introductory text about our study, each participant was randomly assigned to one of three experimental conditions: positive, negative, or control. In the positive text condition, participants read a famous economist's commentary on the benefits of selfinterest; in the negative condition, they read a famous economist's commentary about its negative effects; and in the control condition, they read a famous economist's commentary on the economy of Malaysia. The appendix presents the exact text of each.

The instructions then asked the participants to summarize what they had read, in openended fashion. This was followed by five items asking (on 7-point Likert scales) them to rate the benefits of greed: its impact on profits, organizational efficiency, business success, innovation, and creating a better world. Three additional items using 10-point Likert scales assessed their opinions on the general morality of greed: its goodness, correctness, and morality. Some questions were reverse-coded and their order was randomized. Finally, participants were asked to list up to seven positive things about greed. Reponses to this question were scored for the number of things listed, from 0 to 7 , without consideration of content.

\section{Analyses}


We combined participants' responses into two indices. The first included the five items on the functional benefits of greed (Cronbach's $\alpha=.84$ ); the second included the three items on the general morality of greed (Cronbach's $\alpha=.89$ ). The two indices were positively correlated $(\mathrm{r}=.70, \mathrm{p}<.01)$, suggesting that perceptions of the morality and economic benefits of greed go hand-in-hand. The third and final variable was the number of positive things that our participants listed about greed, a continuous variable ranging from 0 to 7.

\section{RESULTS}

Reading positive statements about self-interest had a positive impact on our participants' attitudes and opinions about greed: a gender $\times$ text ANOVA on the general morality of greed led to a significant effect for text $\left[\mathrm{F}(2,86)=3.36, \mathrm{p}<.05 ; \eta^{2}=.07\right]$ but not for gender $[\mathrm{F}(1,86)=$ 1.64, $p=.20$, n.s., $\left.\eta^{2}=.02\right]$; the interaction was not significant $[F(2,86)=1.47, p=.24]$. Positive text led to more positive moral ratings of greed $(\mathrm{M}=4.48 ; \mathrm{SD}=1.77)$ than negative text $[\mathrm{M}=$ 3.35, $\mathrm{SD}=1.69 ; \mathrm{F}(1,52)=5.82, \mathrm{p}<.05$; Cohen's $d=.40]$; no significant difference emerged for the effects of the negative and neutral texts $[\mathrm{M}=3.76 ; \mathrm{SD}=1.84 ; \mathrm{F}(1,63)=.87$, n.s $]$. Also, although women were less positive about the morality of greed than men, the difference was not significant $\left[\mathrm{M}_{\mathrm{women}}=3.70, \mathrm{SD}=1.72 ; \mathrm{M}_{\mathrm{men}}=4.30 ; \mathrm{SD}=2.02 ; \mathrm{F}(1,90)=1.94, \mathrm{p}=.17\right]$.

Importantly, the different texts did not significantly affect people's views on the functional benefits of greed: their ratings were near the scale midpoint whether their text was positive $(M=4.08 ; \mathrm{SD}=.95)$, negative $(M=3.80 ; \mathrm{SD}=1.08)$, or neutral[$[(\mathrm{M}=3.78, \mathrm{SD}=1.14) ; \mathrm{F}$ $(2,91)=.71 ; p=.50]$. The texts also led to no significant differences on the number of positive items listed about greed $\left[\mathrm{M}_{\text {positive }}=2.74, \mathrm{SD}_{\text {positive }}=1.91\right.$ vs. $\mathrm{M}_{\text {negative }}=2.93, \mathrm{SD}_{\text {negative }}=1.52$ vs. $\left.\mathrm{M}_{\text {neutral }}=2.61, \mathrm{SD}_{\text {neutral }}=1.20 ; \mathrm{F}(2,89)=.35, \mathrm{p}=.70\right]$. These null effects are notable because they mitigate concerns that a positive text might have led to positive reactions towards all perceptions of greed. In spite of different texts, participants seemed to be almost equally aware of the 
functional benefits of greed. The positive text did, however, lead to a significant increase in positive attitudes towards the morality of greed, suggesting that economics education could enhance greed's moral acceptability even for people with minimal prior economic education. Finally, although the results continue to be directionally consistent, gender did not have a significant effect on ratings of the functional benefits of greed $\left[\mathrm{M}_{\text {male }}=4.18, \mathrm{SD}_{\text {male }}=1.15\right.$, vs. $\left.\mathrm{M}_{\text {female }}=3.77, \mathrm{SD}_{\text {female }}=1.02 ; \mathrm{F}(1,90)=2.58, \mathrm{p}=.11\right]$ or the number of positive items listed for greed $\left[\mathrm{M}_{\text {male }}=3.00, \mathrm{SD}_{\text {male }}=1.56\right.$, vs. $\left.\mathrm{M}_{\text {female }}=2.65, \mathrm{SD}_{\text {female }}=1.49 ; \mathrm{F}(1,90)=.91, \mathrm{p}=.34\right]$.

\section{DISCUSSION}

Study 3 reinforces the results of Studies 1 and 2 in an altogether different way. Using a different sample and a direct, but subtle manipulation, it shows that reading a positive text on selfinterest can affect people's attitudes and opinions about greed. Thus, in spite of consistently reprehensive social perceptions of greed, it seems that individuals' feelings about the morality of

greed may not always be set in stone; instead, they seem to be able to be influenced, in this case by short statements by reputable economists. Because a short, single text had immediate effects, it is not hard to imagine that repeated exposure to positive statements about self-interest, provided in an entire course, would have even stronger, longer-lasting effects on people's opinions about greed, including their reactions to their own greedy actions.

Study 3 also addressed the self-selection concern by trying to eliminate its impact experimentally. Although self-interested, greedy people might be more likely to choose economics to be their major (Frank \& Schulze, 2000), these results suggest that, even for people with no exposure to formal economics education, exposure to economic arguments that support self-interest can positively influence their opinions about greed. We suspect that the effect might be stronger for people who have self-selected themselves into economics courses. Future research might further investigate how semester-long economics education can affect the 
behavior and attitudes of people who are less likely to self-select themselves into economics courses.

\section{GENERAL DISCUSSION}

Our research investigated the potential effect of economics education on people's attitudes and opinions about greed. The results show that economics education is consistently associated with positive attitudes towards greed, even after controlling for gender effects and, in Study 3, after addressing the potential effects of self-selection. Although greed is one of the seven cardinal sins, and possibly the mother of them all (Tickle, 2004), regarding the arguments that discuss the benefits of self-interest seems to encourage people to see it more positively. Thus, the uncontested dominance of self-interest maximization as the primary (if not sole) logic of exchange, in business schools and corporate settings alike, may lead people to be more tolerant of what other people see as morally reprehensible (Frank, et al, 1993; Wang \& Murnighan, 2010).

This research sought to make several theoretical and practical contributions. First, it empirically investigated a common but understudied human motivation, which observers often cite as the primary cause of the current global economic crisis (e.g., Bernanke, 2009), and which has recently received an emphatic call for research (e.g. Folger \& Salvador, 2008). People have long viewed greed pejoratively (Robertson, 2001), but these views primarily stem from philosophical and religious beliefs. Our research suggests that, although people generally view greed negatively, their attitudes and feelings about greed are quite malleable.

Second, our research extends the literature about the relationship between economics and self-interest. Although previous studies have suggested that economics education can make people more self-interested and less cooperative (Marwell \& Ames, 1981; Frank, et al, 1993), this research has been repeatedly challenged (Yezer, et al, 1996; Laband \& Beil, 1999; Frank \& Schulze, 2000), particularly because of the possibility of self-selection effects (Frank \& Schulze, 
2000). Our research controlled for self-selection in two ways - by separating the effects of majoring in economics from exposure to multiple economics courses (in Studies 1 and 2) and by experimentally manipulating exposure to the logic of economics for people who had no prior, formal exposure to economics education (Study 3). Our findings continued to support the earlier conclusions, suggesting that economics courses and economic arguments can have a potent impact on people's attitudes and opinions. Thus, our findings clarify and extend earlier findings by suggesting that the study of economics may not only promote self-interest, or behavior that is consistent with the predictions of standard economic models, but may also (unintentionally) encourage greed.

It also appears that the indistinct line between self-interest maximization and greed may help legitimize and possibly even glorify greed. For example, Williams (2000) claims that the "noblest of human motivations is greed," noting that "I don't mean theft, fraud, tricks, or misrepresentation. By greed I mean people being only or mostly concerned with getting the most they can for themselves and not necessarily concerned about the welfare of others." Similarly, in Capitalism and Freedom, Milton Friedman (1962: 133) addressed the pursuit of self-interest with this frequently quoted comment: "The only social responsibility of business is to use its resources and engage in activities designed to increase its profits so long as it stays within the rules of the game."

It is not hard to imagine that actors might use these statements to justify and legitimize their acts of questionable corporate excess (Folger \& Salvador, 2008). As others have noted (e.g., Ferraro, et al, 2005), the language and assumptions of economics have become widely used and accepted, even though they may encourage and strengthen organizational practices that our profession and society actually denounce (Ghoshal, 2005; Pfeffer, 2005; Rocha \& Ghoshal, 2006). As an unfortunate result, greed may be seen as an appropriate, essential, albeit inadvertent ingredient of modern organizations. Given its extremely potent negative externalities, it is not surprising that 
greed conflicts directly with basic moral values in almost all human societies. But people's attitudes and opinions about motives (like greed) depend not only on moral judgments but also on the availability of legitimizing justifications. This opens the door for economics education to subtly encourage and legitimatize the pursuit of greed. Thus, the fact that the bulk of most MBA programs revolves around the concepts and approaches of economics might make us pause; it is possible that a strong emphasis on economics that crowds out other logics is misguided (Bazerman \& Malhotra, 2007).

The current findings provide the basis for a variety of practical implications that are particularly apropos in the aftermath of the recent financial crisis. The management literature already includes several cautionary essays about the format of business education. Ghoshal's (2005) views are a particularly pertinent example (as are Ghoshal and Moran's, 1996). He (and they) presented cogent critiques of an economics approach to business education. The data that we have presented here adds fuel to that fire. Economics education is clearly an essential element in a business professional's toolkit: any lack of understanding of micro- and macroeconomic forces could spell disaster for the economic side of a firm and a society. At the same time, it seems clear that economics education may need to move beyond Adam Smith's notions in the Wealth of Nations, reiterated by Edgeworth $(1881 ; 16)$, that "The first principle of Economics is that every agent is actuated only by self interest." A number of examples contradict these ideas and their implications: people share when they do not need to (e.g., Forsythe, et al. 1988); they are concerned about their own actions, and what their actions say about their character, even when they act privately and can never be observed (Murnighan, Oesch, \& Pillutla, 2001); and, like many other species, they engage in many acts of reciprocal altruism (Trivers, 1971; Simon, 1990). Thus, Machiavelli's highly negative depiction of humanity, that man is "insatiable, arrogant, crafty, and shifting, and above all else malignant, iniquitous, violent and savage, (1965: 
p.736)" is far from universally applicable and may, instead, describe only a select few. The inherent difficulty, of course, is that subscribing to Machiavellian beliefs leads to actions that remove any possibility of understanding the opportunities that exist when we operate with different assumptions (cf., Kelley \& Stahelski, 1970). Thus, business schools might need to inform their students not only about the need to protect against Machiavellians but also about how and when they can benefit from acting cooperatively. The potentially inadvertent messages of economics education, however, might make such a tempered approach even more difficult.

In addition to the implications for business education, the data suggest that an organization's culture can encourage or discourage greed. Like economics education, repeated exposure to language and norms in organizations that relate to profit-maximization, fiduciary responsibility, and the survival of the fittest - to the exclusion of other logics that make salient the impact of our decisions on others - may also contribute to positive attitudes toward greed, leading employees to view greed as necessary, healthy, and beneficial. Whether these feelings spill over to additional social contexts is an important question for future research.

At the same time, our data clearly indicate that people know enough to publicly disparage greed: their self-reported moral attitudes are almost uniformly negative. If greed is a strong and natural human motivation that is only hidden from view via compliance, the threats that it poses for human collectives are serious, as compliance is a particularly weak form of control (Kelman, 1958). This makes the issue of greed that much more important for organizational scholars to pursue.

\section{Limitations and Future Research}

The current research provides new insights into the relationship between economics education and greed. Like any research, our studies have limitations. Study 1 showed that economics students acted more self-interestedly, and arguably greedily, in the Dictator Game. The "greedy" effect of taking an economics course seems strong and robust, but the lack of clear 
conceptual distinctions between greed and self-interest necessarily limit the strength of our conclusions. To address this issue, Study 2 allowed participants to tell their own stories about greed and to present their own definitions of greed. Although the retrospective nature of their stories might have been influenced by recall biases, the data show that economics education was positively associated with attitudes towards greedy behavior and definitions of greed. While we evaluated the effects of an economics major and the effects of taking multiple economics classes, neither set of results could entirely rule out the possibility of a self-selection bias: greedier students may have self-selected themselves into economics courses and economics majors. By focusing on students with no exposure to formal economics education, however, Study 3 avoided the self-selection bias, and still found consistent results. The short-term nature and the limited length of the statements about self-interest in our manipulations suggest that the actual effects of economics education could be much stronger. Overall, the three studies provide consistent, complementary findings (see Figure 2 for a brief summary of the results across the three studies), leading to a stronger and (troublesome) conclusion that economics education may have significant effects on people's attitudes and opinions about greed.

Future research, clearly needed (e.g., Pfeffer, 2005), might further investigate the mechanisms behind our current findings as well the influence of alternative logics and contextual norms as potentially dampening mechanisms, especially since recent research (e.g., Sachdeva, Illev, \& Medin, 2008; Jordan, Mullen, \& Murnighan, 2010) suggests that people's moral interpretations are flexible and subject to other legitimate justifications. Another potent arena for empirical analysis might be an investigation into the particular aspects of economics education that are having these effects. We suspect, for instance, that economics' emphasis on numerical analyses and calculations - both critical components of rigorous decision analysis — can blunt decisions makers' abilities to see the social consequences of their decisions: if leaders only focus 
on financial analyses and balance sheet line items, their decisions may not consider their social effects. Third, future research might evaluate whether the effects of economics courses on greedrelated attitudes and behaviors are most effectively mitigated by redesigning existing economics courses or by exposing students to separate courses that provide a different perspective on economic decisions. Finally, future research that examines the anatomy of economic decision making in situ - for example, by those with different levels of economics training who are working in investment banks or private equity firms, for instance — might provide tremendous insight into how such decisions take shape in context. Thus, we hope that future studies identify both encouraging and discouraging factors, individually and organizationally, as well as educationally.

\section{CONCLUSIONS}

Our research documents a positive relationship between economics education and attitudes towards greed. Most importantly, perhaps, we show that people's perceptions of greed, and their willingness to engage in — and justify — greedy behavior, are malleable. Thus, business schools and their faculty might take note and work to discover ways to minimize the undesirable, unintended consequences of their curricula. 


\section{REFERENCES}

Balot, R. K. 2001. Greed and Injustice in Classic Athens. Princeton: Princeton University Press.

Bazerman, M. H. \& Malhotra, D. 2006. Economics wins, psychology Loses, and society pays.

In Social Psychology and Economics, D. de Cremer, J. K. Murnighan, \& M. Zeelenberg

(Ed.), 263-280. Mahwah, N.J.: Lawrence Erlbaum.

Bernanke, B. 2009. Speech at the Brookings Institution, Washington, DC, September 13.

Cameron, S. 2003. The Economics of Sin: Rational Choice or No Choice At All? Cheltenham,

UK: Edward Elgar.

Carpenter, J. P., Verhoogen, J. \& Burks, S. 2005. The effect of stakes in distribution experiments. Economics Letters, 86, 393-398.

Carter, J. \& Irons, M. 1991. Are economics different, and if so, why? Journal of Economic Perspectives, 5 (2), 171-77.

Cassidy, J. 2002. The greed cycle: How the financial system encouraged corporations to go crazy. The New Yorker, September 23, 2002.

Cialdini, R. B., Kallgren, C. A., \& Reno, R. R. 1991. A focus theory of normative conduct: A theoretical refinement and reevaluation of the role of norms in human behavior. In M. P. Zanna (Ed.), Advances in experimental social psychology, 24: 201-234. New York: Academic Press.

Coombs. C.H. 1973. Reparameterization of the prisoner's dilemma game. Behavioral Science, 18: $424-428$.

Deutsch, M., Coleman, P. T., \& Marcus, E. C. 2000. The Handbook of Conflict Resolution:

Theory and Practice. San Francisco: Jossey Bass.

Eckel, C.C. \& Grossman, P. J. 1998. Are Women Less Selfish Than Men? Evidence from

Dictator Experiments. The Economic Journal, 108 (448), 726-735.

Economists. 2002. Is greed good? May 16th, 2002. 
Edgeworth, F. Y. 1881. Mathematical Psychics: an Essay on the Application of Mathematics to the Moral Sciences. London: Kegan Paul \& Co..

Eisenberg, N. 2000. Emotion, regulation and moral development. Annual Review of Psychology, $51,665-697$.

Etzioni, A. 1988. The moral dimension: Toward a new economics. New York: Free Press.

Ferraro, F, Pfeffer, J. \& Sutton, R. I. 2005. Economics language and assumptions: how theories can become self-fulfilling. Academy of Management Review, 30, 8-24.

Fehr, E., \& Gintis, H. 2007. Human motivation and social cooperation: Experimental and analytical foundations. Annual Review of Sociology, 33: 43-64.

Financial Times, 2002. The Barons of Bankruptcy, July 31, 2002.

Folger, R. \& Salvador, R. 2008. Is management theory too "self-fish"? Journal of Management, 1127-1151.

Forsythe, R., Horowitz, J. L, Savin, N.E. \& Sefton, M. 1994. Fairness in simple bargaining experiments. Games and Economic Behavior, 6, 347-369.

Frost. S. E. Jr. 1962. Basic Teaching of the Great Philosophers. New York: Anchor Books.

Frank, R. H., Gilovich, T. \& Regan, D. T. 1993. Does studying economics inhibit cooperation? Journal of Economic Perspectives, 7, 159-171.

Frank, R. H., Gilovich, T. \& Regan, D. T. 1996. Do Economists make bad citizens? Journal of Economic Perspectives, 10, 187-192.

Frank, R. H. 1988. Passions Within Reason. New York: W. Norton.

Frank, B. \& Schulze, G. G. 2000. Does economics make citizens corrupt? Journal of Economic Behavior and Organization, 43, 101-113.

Friedman, M. 1962. Capitalism and Freedom. Chicago: University of Chicago Press. Gauthier, D. 1986. Morals by Agreement. Oxford: Clarendon Press. 
Ghoshal, S. 2005. Bad management theories are destroying good management practices. Academy of Management Learning and Education, 4, 75-91.

Ghoshal, S., \& Moran, P. 1996. Bad for practice: A critique of the transaction cost theory. Academy of Management Review, 21, 13-47.

Gimein, M. 2002. The Greedy Bunch. Fortune, September 2, 2002.

Ginzel, L. 1994. The impact of biased inquiry strategies on performance judgments.

Organizational Behavior and Human Decision Processes, 57, 411-429.

Güth, W., R. Schmittberger, \& B. Schwarze. 1982. An experimental analysis of ultimatum bargaining. Journal of Economic Behavior and Organization, 3, 367-388.

Haidt, J. 2003. Elevation and the positive psychology of morality. In C.L. Keyes \& J. Hadit (Ed). Flourishing: Positive Psychology and the Life Well-lived, 275-289. Washington, DC: American Psychological Association.

Hirschman, A. O. 1977.The Passions and the Interests. Princeton: Princeton University Press. Jordan, J., Mullen, E., \& Murnighan, J. K. 2010. On the pendulum of moral action: contrasting effects of own and others' past moral actions on future moral behavior. Working Paper, Kellogg School of Management, Northwestern University, Evanston, IL.

Kelley, H.H., \& Stahelski, A.J. 1970. The inference of intention from moves in the Prisoner's Dilemma Game. Journal of Experimental Social Psychology, 6, 401-419.

Kelman, H. C. 1958. Compliance, identification, and internalization, three processes of attitude change. Journal of Conflict Resolution, 2 (1), 51-60.

Kroll, J. \& Egan E. 2004. Psychiatry, moral worry, and moral emotions. Journal of Psychiatry Practice, 10, 352-360.

Laband, D. N. \& Beil, R. O. 1999. Are economists more selfish than other 'social' scientists? Public Choice, 100, 85-101. 
Lerner, M. 1937. Introduction to Adam Smith's The Wealth of Nations. New York: The Modern Library.

Loewenstein G, Thompson L, Bazerman M. H. 1989. Social utility and decision making in interpersonal contexts. Journal of Personality and Social Psychology. 57:426-41.

Machiavelli, N. 1965. Tercets on Ambition. in Machiavelli: The Chief Works and Others. (trans. By A. Gilbert), p. 736. Durham, Duke University Press.

Marwell, G. \& Ames, R. 1981. Economists free side, does anyone else?: Experiments on the provision of public goods, IV,” Journal of Public Economics, 15 (3), 295-310.

McCabe, D. L., Butterfield, K. D. \& Trevino, L. K. 2006. Academic dishonesty in graduate business programs: Prevalence, causes, and proposed action. Academy of Management Learning and Education, 5 (3), 294-305.

McCabe, D. L, Dukerich, J. M. \& Dutton, J .E. 1993. Values and Moral Dilemmas: A CrossCultural Comparison. Business Ethics Quarterly, 3, 117-130.

McCabe, D., Dukerich, J. \& Dutton, J. 1993. Context, values and Moral Dilemmas: comparing the Choices of Business and Law School Students. Journal of Business Ethics, 10, 951-960.

Messick, D. 1995. Equality, fairness, and social conflict. Social Justice Research, 8, 153-170. Murnighan, J. K. 1991. The Dynamics of Bargaining Games. Englewood Cliffs, NJ: Prentice Hall.

Murnighan, J. K., Cantelon, D. A., and Elyashiv, T. 2001. Bounded personal ethics and the tap dance of real estate agency. In J. Wagner, J. Bartunek, and K. Elsbach (Eds.), Advances in Qualitative Organizational Research, 3: 1-40. New York: Elsevier/JAI.

Murnighan, J. K., Oesch, J., \& Pillutla, M. M. 2001. Player types and self impression management in dictatorship games: Two experiments. Games and Economic Behavior, $37,388-414$. 
Obama, B. 2009. Remarks By The President To General Motors Plant Employees. General Motors Lordstown Assembly Plant, Warren, Ohio. September 15.

Pfeffer, J. 2005. Why do bad management theories persist? A comment on Ghoshal. Academy of Management Learning and Education, 4 (1), 96-100.

Pfeffer, J. 1993. Barriers to the advance of organizational science: Paradigm development as a dependent variable. Academy of Management Review, 18, 599-620.

Rand, A. 1957. Atlas Shrugged. New York: Signet.

Rapoport, A. and Chammah, A. M. 1965. Prisoner's Dilemma: A Study in Conflict and Cooperation, Ann Arbor: University of Michigan Press.

Robertson, A. F. 2001. Greed: Gut feelings: Growth, and History. Cambridge: Polity Press.

Rocha, H. O., \& Ghoshal, S. 2006. Beyond self-interest revisited. Journal of Management Studies, 43: 585-619.

Ross, L., Greene, D. \& House, P. 1977. The "false consensus effect": An egocentric bias in social perception and attribution processes. Journal of Experimental Social Psychology, $13,279-301$.

Sachdeva, S., Illev, R., Medin, D. 2009. Sinning saints and saintly sinners: the paradox of moral self-regulation. Psychological Science, 20, 523-528.

Sagarin, B, J., Rhoads, K.v. L. \& Cialdini, R. B. 1998. Deceiver's distrust: denigration as a consequence of undiscovered deception. Personality and Social Psychology Bulletin, 24, 1167-76.

Schwartz, B. 1986. The Battle for Human Nature: Science, Morality and Modern Life. New York: W. W. Norton \& Company.

Schwarz, N., Groves, R.M, \& Schuman, H. 1998. Survey methods. In D.T. Gilbert, S.T. Fiske, \& G. Lindzey (Eds.), The Handbook of Social Psychology, Vol. 1 (4th ed.) (pp. 143-179). 
Boston, MA: McGraw-Hill.

Seguino, S., Stevens, T. \& Lutz. M. A, 1996. Gender and Cooperative Behavior: Economic Man Rides Alone. Feminist Economics, 2(1), 1-21.

Sen, Amartya. 1987. On Ethics and Economics. New York: Basil Blackwell Publishers.

Simon, H. 1990. A mechanism for social selection and successful altruism. Science, 250: $1665-1668$.

Smith, Adam 1776/2007. The Wealth of Nation (With an Introduction and Notes by Jonathan B. Wight). Hampshire, UK: Harriman House.

Smith, Adam, 1759/2002. The Theory of Moral Sentiments. (Ed. By K. Haakonssen). Cambridge, UK: Cambridge University Press.

Stanley, T. D. \& Tran U., 1998. Economics students need not be greedy: fairness and the ultimatum game. The Journal of Socio-Economics 27(6), 657-663.

Stigler, G. 1971. Smith's travels on the ship of state. History of Political Economy, 3, 265-277.

Stigler, G. 1980. Economics or Ethics? In S. McMurin. (Ed.) Tanner Lectures in Human Values, Vol. II. Cambridge: University Press.

Tangney, J. P., Stuewig, J. \& Mashek, D. J. 2007. Moral emotions and moral behavior. Annual Review of Psychology, 58, 345-372.

Tickle, P. 2004. Greed: The Seven Deadly Sins. Oxford University Press.

Trivers, R. L. 1971. The evolution of reciprocal altruism. Quarterly Review of Biology, 46, 3557.

Vohs, K. D., Mead, N. L., and Goode, M. R. 2008. Merely activating the concept of money changes personal and interpersonal behavior. Current Directions in Psychological Science, 17, 208-212.

Wang, L. \& Murnighan, J. K. 2010. On the Duality of Greed. Working Paper, Kellogg School of 
Management, Northwestern University, Evanston, IL.

Weingart, L. 1997. How did they do that? The ways and means of studying group process. In L.L. Cummings \& B. Staw (Eds.) Research in Organizational Behavior, (Vol. 19) Greenwich, CT: JAI Press.

Werhane, P. H. 1991. Adam Smith and His Legacy for Modern Capitalism. New York: Oxford University Press.

Williams, W. E. 2000. Greed Versus Compassion. Freeman: Ideas on Liberty. 50(10). http://www.fee.org/publications/the-freeman/article.asp?aid=2456

Williamson, O.E. 1984. The economics of governance: Framework and implications. Journal of Institutional and Theoretical Economics, 140(1), 195-223.

Williamson, O. E. 1994. Transaction cost economics and organization theory. In Neil J. Smelser and Richard Swedberg (Eds.), Handbook of Economic Sociology: 77-107. Princeton: Princeton University Press.

Wilson, J. 2007. Shielding money clashes with elders' free will. The New York Times, December 24,2007

Yezer, A. M., Goldfarb, R. S. \& Poppen, P. J. 1996. Does studying economics discourage cooperation? Watch what we do, not what we say or how we play. Journal of Economic Perspectives, 10 (1), 177-186.

Zhong, C. B. 2008. The ethical dangers of rational decision making. Academy of Management Best Papers Proceedings, Anaheim. 
TABLE 1 Mean Dollar Amounts Kept by Economics and Education Student Dictators when they were not restricted in how they distributed $\$ 10$ and when they had only two choices: equal division $(\$ 5-\$ 5)$ or advantageously unequal ( $\$ 9.25$ for self and $\$ .75$ for the other person)

Average Dollar Amounts Kept in Each Task

\begin{tabular}{|c|c|c|c|}
\hline & Economics Students & Education Students & $\underline{\text { All Students }}$ \\
\hline Unrestricted $\$ 10$ & $\$ 7.80$ & $\$ 6.26$ & $\$ 7.17$ \\
\hline Restricted $\$ 10$ & $\$ 7.72$ & $\$ 6.74$ & $\$ 7.32$ \\
\hline All Tasks & $\$ 7.76$ & $\$ 6.50$ & $\$ 7.24$ \\
\hline
\end{tabular}




\begin{tabular}{|c|c|c|c|c|c|c|c|c|c|c|}
\hline \multicolumn{11}{|c|}{ Table 2: Correlations and Summary Statistics; Sample: 166 observations; } \\
\hline & & Mean & S.D. & 1 & 2 & 3 & 4 & 5 & 6 & 7 \\
\hline 1 & Post-hoc feelings & 2.84 & 1.30 & - & & & & & & \\
\hline 2 & Moral evaluation & 1.61 & 1.15 & $.33 * *$ & - & & & & & \\
\hline 3 & Definition & .44 & .50 & -.06 & -.05 & - & & & & \\
\hline 4 & Gender & 1.60 & .49 & $-.23 * *$ & $-.27 * *$ & .02 & - & & & \\
\hline 5 & Major & 1.66 & .47 & .07 & .15 & $-.23 * *$ & $-.41 * *$ & - & & \\
\hline 6 & $\begin{array}{l}\text { Exposure to Econ } \\
\text { ( } 2 \text { vs. } 3 \text { or more) }\end{array}$ & 1.67 & .47 & $.17^{*}$ & $.21 * *$ & $-.20 * *$ & $-.34 * *$ & $.45^{* *}$ & - & \\
\hline 7 & $\begin{array}{l}\text { Exposure to Econ } \\
\text { (1 vs. } 2 \text { or more) }\end{array}$ & 1.44 & .50 & $.20 * *$ & $.20 * *$ & $-.17 *$ & $-.37 * *$ & $.50 * *$ & $.62 * *$ & - \\
\hline
\end{tabular}




\begin{tabular}{cc}
\hline Table 3: Standardized Beta Coefficients from Logit \\
Regression Analysis of the Effects of Major, Gender, and \\
Exposure on Greed Definition \\
\hline Variable & Model 1 \\
Major & $-1.03^{*}$ \\
& $(.43)$ \\
Gender & -.50 \\
& $(.39)$ \\
Exposure & -.43 \\
& $(.39)$ \\
Constant & -.56 \\
$\chi^{2}$ & $(1.19)$ \\
\hline Log Likelihood & $10.92^{*}$ \\
Pseudo ${ }^{2}$ & 211.65 \\
Overall model F & .09 \\
$\mathrm{~N}$ & $2.22^{*}$ \\
\end{tabular}

$* * p<0.01 ; * p<0.05 ; \uparrow p<0.10$ 


\section{FIGURE 1}

FIGURE1a. The Mean Ratings of the General Morality of Greed by Economics and Non-economics majors who had taken 2 economics courses or less, versus 3 or more

Ratings of the Morality of Greed (1=Immoral; 7=Moral)

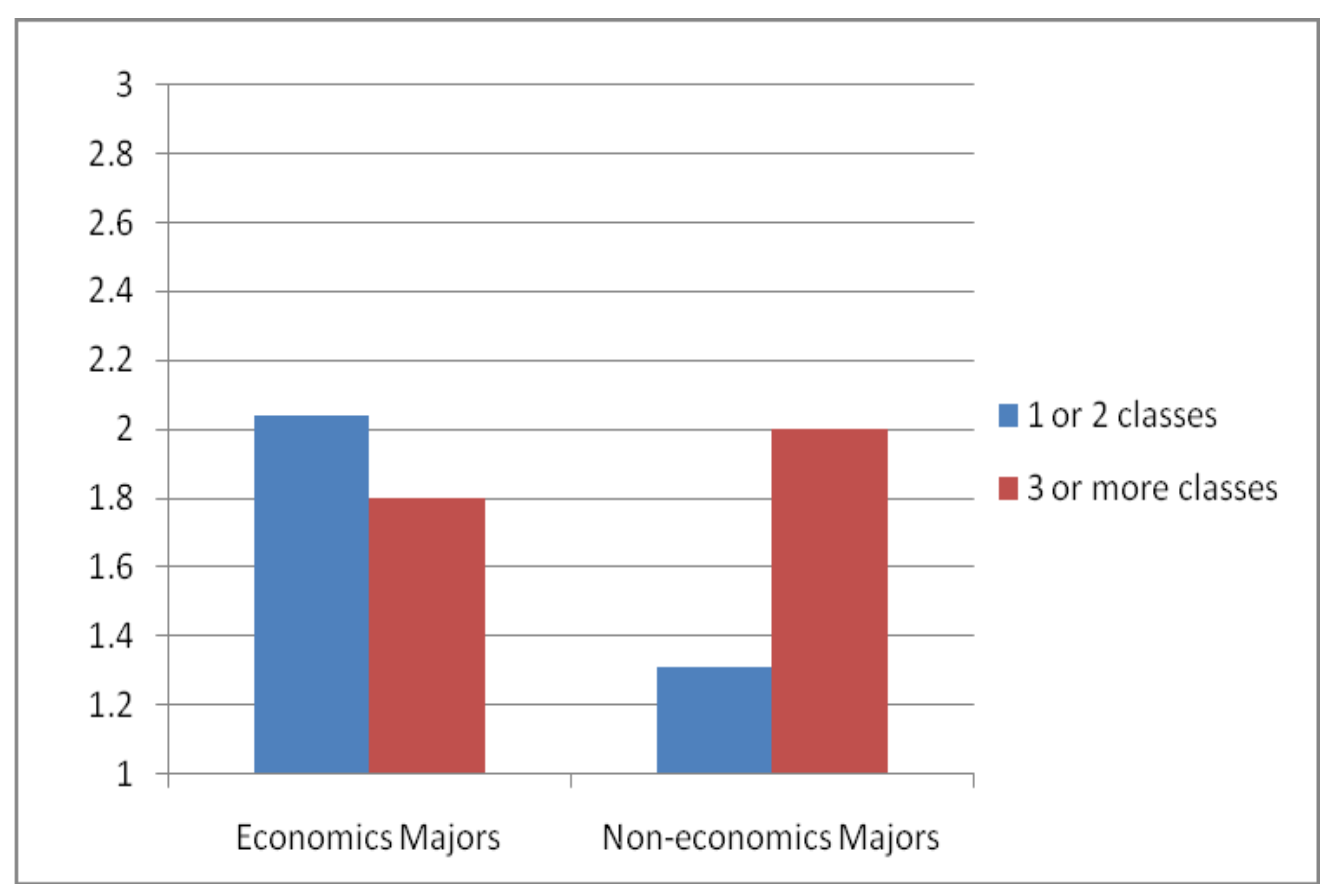


FIGURE 1b. The Mean Ratings of the General Morality of Greed by Male and Female Economics and Noneconomics majors

Ratings of the Morality of Greed ( $1=$ Immoral; 7=Moral)

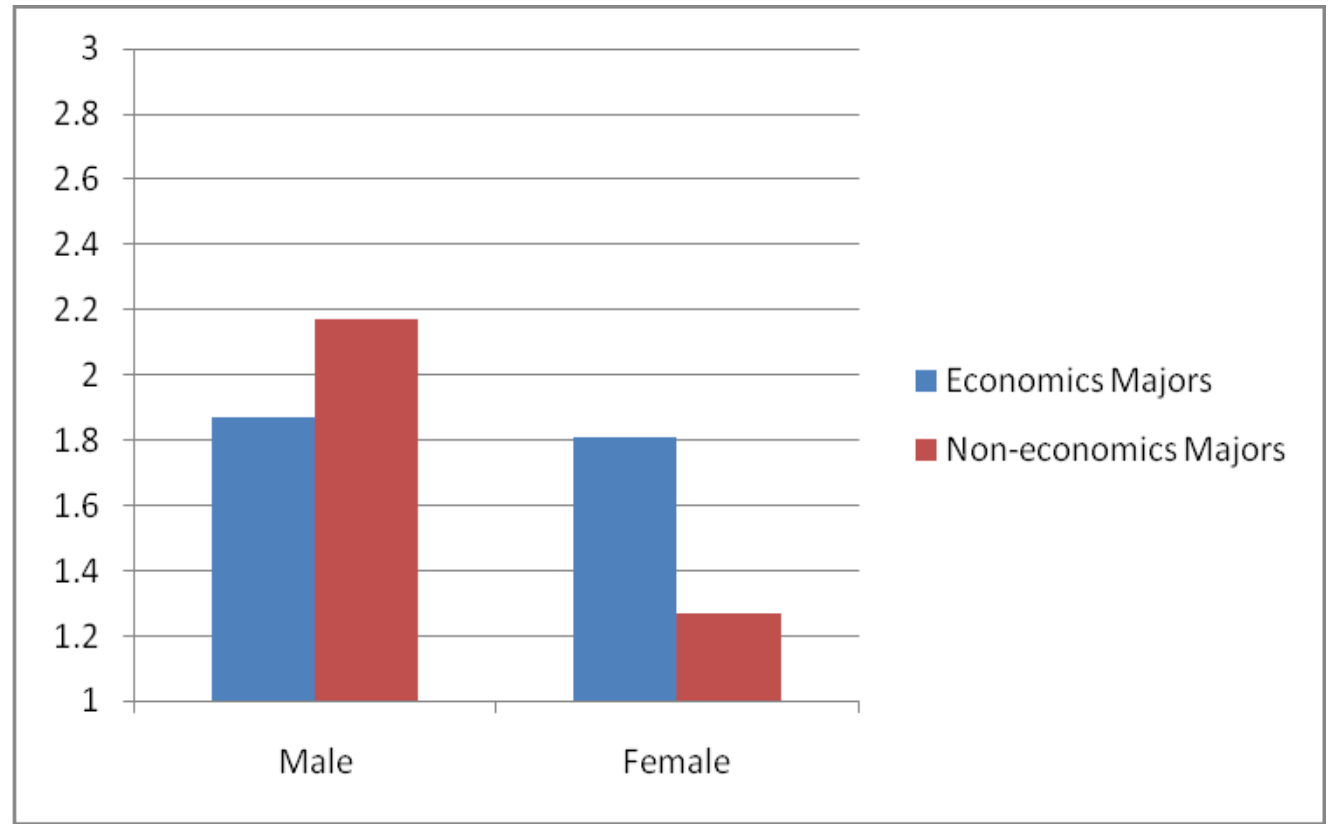


FIGURE 2. A Summary of the Three Studies and Their Major Findings

Study 1

The Dictator Game

Behavioral Task

1. Econ students kept $\$ 7.76 / \$ 10 ; \mathrm{Ed}$ students kept $\$ 6.50 / \$ 10$

2. $56 \%$ of Ed students mentioned

fairness versus $31 \%$ of Econ students

3. 8/13 non-Econ majors in an Econ class

kept $\$ 10$ vs. 1/13non-Ed majors in an Ed

class
Study 2

Self-reported stories

Evaluative ratings of greed

1.Econ major and $3+$ courses: moral ratings of greed increased. $3+$ courses also led to more positive feelings about own greedy actions.

2. Women rated greed as less moral than men if they were not econ majors; they also had more negative feelings about their own greedy actions.

3. Econ majors were less likely to mention greed's social impact

\section{Study 3}

Self-interest statements

Evaluative Ratings of greed

1.Positive statements about self-interest led to positive moral ratings of greed

2.Women rated greed as less moral, but not significantly 


\section{Appendix}

\section{Positive Priming:}

"Self-interest ${ }^{5}$ is good. Self-interest is right. Self-interest works." So said Gordon Gecko, the lead character in the movie, Wall Street. Although this quote may be his most memorable, he continued by saying, "Self-interest clarifies, cuts through, and captures the essence of the evolutionary spirit. Self-interest, in all of its forms -- self-interest for life, for money, for love, for knowledge -- has marked the upward surge of mankind."

This is echoed by Water E. Williams, a notable economist. "For me the noblest of human motivations is self-interest. I don't mean theft, fraud, tricks, or misrepresentation. By self-interest I mean people being only or mostly concerned with getting the most they can for themselves and not necessarily concerned about the welfare of others."...

"Normally in our country, where people are motivated the most by self-interest are the areas that we're most satisfied with-supermarkets, computers, FedEx; and those areas where people say we're motivated by caring are areas of disaster in our country, such as education, the post office, city garbage collection, policy services."

\section{Negative Priming:}

Self-interest can get out of control. "If you have an unregulated arena, cheaters win," says Michael Josephson, a radio commentator and president of the Josephson Institute of Ethics in Marina del Rey, Calif. "But if you have a civil society, which we do, with a series of checks and balances, by all means the honest people can win. ... Honesty and integrity is the way to conduct business."

This is echoed by Paul Krugman, a notable economist. "Now, as each day seems to bring a new business scandal, we can see .... a system that lavishly rewards executives for success tempts those executives, who control much of the information available to outsiders, to fabricate the appearance of success. Aggressive accounting, fictitious transactions that inflate sales, whatever it takes." Ken Lay, Gary Winnick, Chuck Watson, Dennis Kozlowski -we're not talking about a few bad apples. . Statistics for the last five years show a dramatic divergence between the profits companies reported to investors and other measures of profit growth; this is clear evidence that many, perhaps most, large companies were fudging their numbers. "Now, distrust of corporations threatens our stilltentative economic recovery; it turns out self-interest is bad, after all."

\section{Neutral Priming:}

Malaysia, a middle income country, transformed its economy from 1971 through the late 1990s from relying primarily on the production and export of raw materials, into one of the world's leading trading nations in electronics and information technology (IT) goods, says Marc Mealy, a senior director at US-ASEAN Business Council. "Today, utilizing its diverse resource base (energy, raw materials, manufactured goods and information technology products ) and coupled with healthy foreign exchange reserves and relatively small external debt, Malaysia continues its economic success via the promotion of both domestic and foreign based growth engines to help Malaysia achieve its goal of becoming a "developed" nation by the year 2020."

This is echoed by Joseph Stiglitz, a notable economist. "Malaysia has accomplished [since its independence] is impressive - and has much to teach the world, both about economics, and about how to construct a vibrant multiracial, multi-ethnic, multicultural society." "The numbers themselves say a lot. At independence, Malaysia was one of the poorest countries in the world. ... Today, .. [i]n the global growth league tables, Malaysia is in the top tier, along with China, Taiwan, South Korea, and Thailand."

\footnotetext{
${ }^{5}$ The original quotes in both positive and negative primes used the word: "greed." We replaced it with self-interest to make it more consistent with mainstream economic arguments. We also tested the effects of these statements using the word "greed"; this led to even stronger effects.
} 